\title{
QUEEN'S
UNIVERSITY
BELFAST
}

\section{Why are you tall while others are short? Agricultural production and other proximate determinants of global heights}

Baten, J., \& Blum, M. (2014). Why are you tall while others are short? Agricultural production and other proximate determinants of global heights. European Review of Economic History, 18(2), 144-165. https://doi.org/10.1093/ereh/heu003

Published in:

European Review of Economic History

Document Version:

Peer reviewed version

Queen's University Belfast - Research Portal:

Link to publication record in Queen's University Belfast Research Portal

\section{Publisher rights}

This is a pre-copyedited, author-produced PDF of an article accepted for publication in European Review of Economic History following peer review. The version of record "Why are you tall while others are short? Agricultural production and other proximate determinants of global heights". Baten \& Blum European Review of Economic History (2014) 18 (2): 144-165 is available online at:

http://ereh.oxfordjournals.org/content/18/2/144

\section{General rights}

Copyright for the publications made accessible via the Queen's University Belfast Research Portal is retained by the author(s) and / or other copyright owners and it is a condition of accessing these publications that users recognise and abide by the legal requirements associated with these rights.

Take down policy

The Research Portal is Queen's institutional repository that provides access to Queen's research output. Every effort has been made to ensure that content in the Research Portal does not infringe any person's rights, or applicable UK laws. If you discover content in the Research Portal that you believe breaches copyright or violates any law, please contact openaccess@qub.ac.uk. 


\section{Why are you tall while others are short? Agricultural production and other proximate determinants of global heights}

by Joerg Baten* and Matthias Blum**

* University of Tuebingen and CESifo. Address: Melanchthonstr. 30, 72074 Tuebingen, Tel. +49-7071-29-78167, Fax +49-7071-29-5119, E-mail address: joerg.baten@uni-tuebingen.de.

** Technical University of Muenchen (corresponding author). Adress: Weihenstephaner Steig 22, 85354 Freising/Germany. Fax: +49 816171 3030. E-mail address:

matthias.blum@tum.de.

Acknowledgements: We thank all of those who provided data and comments, notably, JeanPascal Bassino, Barry Bogin, Greg Clark, Peter Coclanis, Dorothee Crayen, Ricardo Godoy, Aravinda Guntupalli, Bernard Harris, Timothy Hatton, Laurent Heyberger, John Komlos, Michał Kopczyński, Moramay López-Alonzo, Kerstin Manzel, Adolfo Meiselmann, Alexander Moradi, Stephen Morgan, Boris Mironov, Ilkka Nummela, Deborah Oxley, Sunyoung Pak, Valeria Prayon, Sonja Rabus, Inas Rashad, Ricardo Salvatore, Daniel Schwekendiek, Richard Steckel, Mojgan Stegl, Yvonne Stolz, Linda Twrdek, and three anonymous referees. Comments on earlier versions of this paper by conference and seminar participants in Barcelona, Durham, Kiel, Kyoto, Lisbon, Munich, Oxford, Strasbourg and Tübingen are gratefully acknowledged as well. Financial background support by the ClioInfra project of the National Science Foundation of the Netherlands (N.W.O.) and the DFG SFB 1070 'ResourceCultures' for background data work is gratefully acknowledged. 


\title{
Why are you tall while others are short? Agricultural production and other proximate determinants of global heights
}

Word count: 8697 incl. footnotes and references (excluding online appendices and figures/tables)

\begin{abstract}
:
We analyze the proximate determinants of the biological standard of living from a global perspective, namely, high-quality nutrition and the disease environment during the $19^{\text {th }}$ and $20^{\text {th }}$ centuries. Until the mid- $20^{\text {th }}$ century, the local availability of cattle, meat, and milk per capita and the local disease environment mainly determined the stature of the population and, by implication, how long they lived and how healthy they were. During the late $20^{\text {th }}$ century, the trade of agricultural products and health-promoting technologies increased in relative importance; hence, the local availabilities became less decisive in explaining height differences.
\end{abstract}

Keywords: nutrition, stature, height, economic history, $19^{\text {th }}$ century, $20^{\text {th }}$ century JEL Codes: N50, O13 


\section{Introduction}

Federico (2005) describes agricultural development over the last two centuries as an outstanding success story. Agriculture has succeeded in feeding a growing population, producing a variety of products at falling prices, and enabling, through efficiency gains, many members of the agricultural labor force to be active in other sectors. By analyzing the increasing inputs to agricultural production, such as physical and human capital, the substitution of labor with machinery, and the growing efficiency due to technological and technical advances, Federico finds that the productivity increase in agriculture was even greater than that in manufacturing.

However, for the agricultural development to truly be considered a success - at least from a welfare-based perspective - the impact of agricultural production on consumption must first be determined. While production and productivity may have grown, the welfare outcome is less clear, especially in poorer world regions (Clark 2007). Apart from this significant inequality issue, losses of perishable products during transport and storage are also crucial factors when assessing global nutrition and welfare trends. Therefore, this study assesses the outcome of the aforementioned success story and its relevance to human nutrition using anthropometric methods (Fogel et al. 1982, Steckel 2009, Komlos and Baten 2004, Floud, Fogel, Harris and Wong, Hatton 2013).

We examine these topics using average male height as a metric proxy for health and net nutritional status, which could be partially determined by a set of production indicators as proxies for the production of high-quality foodstuffs. In addition, infant mortality is used as a proxy for health, and several control variables are taken into consideration. The impact of animal protein and calcium on anthropometric values has been described in terms of a bottleneck (Baten 2009) - the concept implying that producing animal protein is expensive, particularly in densely populated areas. The historical record indicates that humans have always required large quantities of protein, in particular animal protein, such as milk and meat, to obtain micronutrients, such as calcium, and to generate antibodies and essential amino acids deficient in plant proteins. These externally provided nutrients help to fight infectious diseases and eventually lead to taller final adult body 
height (Grigg 1995, Baten 1999). De Beer's (2012) meta-analysis of clinical studies reveals that the most likely effect of dairy products supplementation is $0.4 \mathrm{~cm}$ per annum additional growth per approx. $245 \mathrm{ml}$ of milk daily. Milk seems to have a greater effect on growth than other dairy products. ${ }^{1}$ Conversely, if nutritional intake is insufficient or if factors such as disease or hard labor divert energy, body growth is severely retarded, and the body cannot fully compensate for growth deceleration if conditions do not improve markedly later in childhood or adolescence (Steckel 1995, Blum 2011, 2013a).

The interactions between stature, nutrition and health have been investigated by a number of country case studies, including the U.S. and the Habsburg Empire (Komlos 1985, 1987, Haines, Craig and Weiss 2003). In this study, however, we use a large panel dataset to assess the relationship between nutritional standards, mortality and height among 156 countries during the $19^{\text {th }}$ and $20^{\text {th }}$ centuries.

Crafts (2002) and, more recently Prados de la Escosura (2010) have calculated historical Human Development Indices, as they argued that income should be complemented by other components such as longevity and education. Prados de la Escosura found that the "Rest" as he defines it (the pre-1994 non-OECD members) caught up during its demographic transition phase between WWII and about 1970. After 1970, in spite of rising education, convergence in HDI overall and longevity in particular vanished according to his estimates.

Similar to these authors, we depart for the health-related aspects of the standard of living from the health production function literature (Preston 1975, Easterlin 1999, Hatton 2013). The health production describes the relationship between income and health as a concave function $\left(\mathrm{HPF}_{1}\right.$ in Figure 1, see Preston 1975). As income grows from $\mathrm{Y}_{1}$ to $\mathrm{Y}_{2}$ and finally $\mathrm{Y}_{4}$, health also improves, but the marginal increase of health becomes smaller with each unit of income. Easterlin (1999) argues that most of the health improvement during the $20^{\text {th }}$ century was caused by the

\footnotetext{
${ }^{1}$ In addition, lower initial height-for-age and belonging to the 10-19 age group increased height effects in food supplementation studies.
} 
improving disease environment, represented in the figure by the shift from $\mathrm{HPF}_{1}$ to $\mathrm{HPF}_{2}$. At the same level of income, a better disease environment results in higher health values.

Hatton (2013) explains that most of the health production function literature interprets income in terms of food consumption, without considering the composition. Hence an alternative interpretation of the shift from $\mathrm{HPF}_{1}$ to $\mathrm{HPF}_{2}$ could also be different agricultural specializations. Countries specialized in dairy farming, for example, might have followed $\mathrm{HPF}_{1}$, whereas countries in which only starches were produced might have followed $\mathrm{HPF}_{2}$ - especially during the $19^{\text {th }}$ and early $20^{\text {th }}$ centuries, when transport technology did not allow protein trade to the same degree as it did later.

\section{[FIGURE 1 HERE]}

\section{The development of agricultural output}

During the $19^{\text {th }}$ and $20^{\text {th }}$ centuries, world agricultural production experienced significant increases due to growing inputs, technological improvements, and a series of institutional changes, such as market reforms, property rights and the role of policy makers (Federico 2005). However, these increases were not uniform around the globe. In most countries for which evidence is available, the total agricultural output has increased during the past two centuries as indicated by growth rates ranging from 0.5 to $0.6 \%$ in Austria, Belgium and Spain to $3 \%$ and $8.7 \%$ in the U.S. and Australia, respectively. While agricultural production in (today's) OECD countries increased 2.4 times between 1800 and 1870 (Federico 2005), anthropometric evidence suggests that per-capita nutrition did not necessarily improve (Steckel 1995, Komlos 1998). Some authors report that during the early and mid-19 $19^{\text {th }}$ century, nutritional standards stagnated or even worsened in some parts of the world and that average height, in many cases, did not begin to increase until the late $19^{\text {th }}$ century (Zehetmayer 2011).

For post-1870 periods, agricultural output data are more abundant, thus allowing for comparisons between and among time-periods and world regions. The growth rates presented in 
Table 1 indicate that agriculture grew faster between 1870 and 1913 as a result of decades without major shocks and rapid economic development, in general. Conversely, the war and inter-war period of 1913 to 1938 prevented the continuation of this positive pre-war development. Only Latin America was left almost unscathed during the 1913 to 1938 period, which is reflected by impressive growth rates during both of the aforementioned periods (Federico 2005, Maddison 2001). In Eastern Europe, Asia and the Western settlements, populations grew faster than agricultural output, which is indicated by bolded characters in Table 1 . This indicates a substantial pressure on available food resources, which typically are only partially offset by food imports. In Asia and Oceania, population pressures on food resources continued until the 1950s. After 1960, this food pressure became most catastrophic in Africa, where the population grew much more than the agricultural output and net imports could not be financed by export revenues. This also occurred, though not to the same severe degree, in the Soviet Union and its successor states. Federico (2005), citing WTO estimates, reports - for the whole world - an average total annual growth rate of $2.3 \%$ between 1950 and 2000 . This growth rate enabled a tripling of world agricultural output, whereas the world population increased only by a factor of 2.4. This indicates that both total and per-capita productions grew at an impressive pace, potentially leading to superior nutritional standards (Table 2).

[TABLE 1 AND 2, AND FIGURE 2 HERE]

In addition to the mere increase in the quantities produced, a significant change in the composition of food production is observable, especially regarding the pre-WWI period. While both the output of crops and livestock increased, rising production capacities also allowed moving from producing low-quality foodstuffs toward more expensive, high-quality foodstuffs, as indicated by the livestock-crop ratio (Figure 2). While this development reflects increasing production capabilities, it also indicates a change in purchasing power of consumers in many of the rapidly developing countries. Furthermore, though output levels continued to increase during the second 
half of the $20^{\text {th }}$ century, there was no clear trend evident in the livestock-crops ratio (Federico 2005).

However, Tables 1 and 2 also indicate that growth rates differed among world regions and periods. As openness to trade and the technological possibilities to store and transport foodstuffs changed, differences between production and consumption were not necessarily equal to the development of nutrition among world regions and over time (Salvatore 2004b).

\section{Methodology and data}

Data used in this study include Baten and Blum's (2012a) average male height compilations from 156 countries and span the $19^{\text {th }}$ and $20^{\text {th }}$ centuries (Table 3 ). All country estimates are organized by birth decades, and the panel of height estimates is analyzed using a set of explanatory variables.

Two questions must be addressed regarding this study. How comparable were different height samples for the various countries included in this database? How substantial were the various selectivities of the measured individuals? First, some typically biased samples - such as samples of students - were not included in the national height estimates considered in our study. In general, preference was given to military conscript samples and systematic anthropological measurements. The military conscript samples became available after the concept of general conscription in the French revolutionary and Napoleonic armies spread throughout continental Europe around 1800. Typically, every male of a certain age was measured and medically examined (thereafter, the lot determined who joined the army). The files, to the extent that they survived, recorded everyone's height, except for the small share of illegal emigrants (clergymen were also exempt). Hence, height estimates based on this system are more representative than volunteer armies. Anthropological measurements, which were conducted in many developing countries beginning in the 1970s and 1980s, were also a very comprehensive source with little underlying selectivity. However, the 
earliest anthropological measurements of the late $19^{\text {th }}$ century were sometimes more difficult to use because they were often quite localized. Only if a country was documented by a large number of regional measurements (representing the various regions) could representativeness for national means be assumed. ${ }^{2}$ For some countries and periods, only samples of prisoners, slaves and volunteer soldiers were available. In those cases, selectivities were slightly more difficult to assess. However, for most of the countries, several sources were available, and hence, a comparison of height trends and levels recorded in different contexts was possible. Baten and Blum (2012a) also ensured that no substantial regional biases were present in the height series that was ultimately selected for a specific country (especially in large countries where regional height differences can be substantial). One obvious problem in volunteer armies and prison samples is the dependence on the opportunity costs as determined by the labor market. The preferred strategy in this case was to assess height samples that were recorded for only one year (or for a short span of time, such as the U.S. Civil War 1861-65) and that contained different age groups. This allowed to keep the labor market conditions constant at the time of recruitment so that height, when organized by birth cohort, could be analyzed. A number of recent studies also have used the basic numeracy of sampled individuals in comparison with census-based numeracy estimates to assess potential sample selectivity bias (firstly done in Stegl and Baten 2009). ${ }^{3}$

In order to assess how large the problem of sample selection bias might be potentially, we also did a robustness test using a puristic strategy and repeated the regressions of table 6 (discussed below) with only those observations which stemmed either from (a) conscript armies in which male inviduals were measured in a representative way or (b) from Demographic and Health Surveys or anthropological surveys in which the inviduals were measured without social composition bias or potential labour-market-based sample selection biases. As a small minority of the samples falling under category (b) might

\footnotetext{
${ }^{2}$ The very earliest anthropological data could sometimes not be used as anthropologists sometimes intended to find certain extremes (such as "the tallest African tribe," etc.).

${ }^{3}$ For additional information on the height data set, see Appendix B.
} 
not be regionally representative for the whole country, we identified for each country those studies which could potentially suffer from regional or urban-rural bias. This puristic exercise resulted in dropping 73 of the 604 country-birth decade observations which were previously included in column 2 of Table 6. Calculating the share of observations which might be considered suspicious by some sceptic readers results only in a loss of between 9.1 and 12.1 percent of our overall sample. Conversely, around 90 percent of our observations are based on either representative military conscription or anthropological surveys. We assessed the remaining 10 percent further and would argue that they are mostly unaffected by sample selection bias, except perhaps for a small minority of cases, which we cannot clearly identify based on the information available to us in the - especially olderanthropological survey reports.

\section{[TABLE 3 AND 4 HERE]}

The main result is that the estimation using the reduced sample yields virtually identical results (Table C.3). None of the coefficients deviates by more than 10 percent. The cattle factor might be slightly larger and the GDP effect slightly less important, but the size categories and levels of significance are very close to being identical. ${ }^{4}$

One important question to address regards catch-up growth. That is, if an epidemic disease retards the growth of a child only temporarily (or if there is a temporary famine), catch-up growth later in childhood or adolescence will bring the stature to almost the same level as if the temporary retardation had not happened. For example, the famine in Rotterdam 1944/45 was famous in this respect. When the German troops retreated during WWII, they isolated Rotterdam from any food imports for a number of months. While the population suffered from a terrible famine, Dutch anthropologists determined later that due to catch-up growth, this did not leave a permanent mark

\footnotetext{
${ }^{4}$ For a similar robustness test on the minimum number of cases per country and birth decade, see Appendix C.
} 
on the part of the population that were children during the time of the famine. However, if bad conditions would have remained, permanent stunting would have been the effect, as in many other countries and periods.

Data on lactose tolerance, which will later be used in the analysis as an instrumental variable, are compiled from Ingram et al. (2009) and Flatz (1995). Ingram et al. (2009) performed an interesting compilation research on lactose tolerance, compiling almost 450 studies on countries and regions within countries. Almost all of these studies relied on the experiment and addressed the following question. Did the consumption of a typical amount of milk contribute to small increases in blood glucose levels and in breath hydrogen levels? The typical samples ranged between 10 and 99, as samples larger than 100 were rare. Ingram et al. also carefully investigated and recorded whether sufficient context information was provided in the original studies. They determined that extreme lactose tolerance or intolerance is exceptionally rare as, typical values ranged between 30 and $70 \%$ for the majority of the world regions. The only large areas with very low tolerance (< $10 \%$ ) are Southeast Asia (including South China) and the South Angola-Namibia-Botswana region. Interestingly, the latter region has a large amount of cattle per capita. Northwestern Europe and the Senegal-Mali region in West Africa had high numbers of lactose-tolerant individuals. Smaller regions with lactose digesters were situated in Pakistan/Northwest India, Saudi-Arabia and East Africa. In general, areas suitable for raising cattle demonstrated increased lactose tolerance (except with respect to Angola-Namibia-Botswana).

The other variables included are derived from standard sources (Table 4). Information on cattle, milk and meat are taken from Mitchell (1980, 1982, 1983), World Bank Development Indicators, Federico (2005) and Hübner (several years). Infant mortality is compiled using Collver (1965), Mitchell (1980, 1982, 1983) and Chesnais (1986). Mountainous terrain and civil war data are taken from Collier and Hoeffler (2004) and the correlates of the war database (initiated by Singer and Small 1972 and regularly updated), respectively. Civil war is coded as a dichotomous variable adopting the value 1 if a country experienced a civil war during a ten-year period. The database only contains 
information on those conflicts that caused at least 1,000 battle-related deaths (of all participants) per conflict year. ${ }^{5}$ The democracy index is taken from the Polity IV Project (Marshall and Jaggers 2008; averages for the countries have been included).

One important methodological decision was to use proximate determinants of height in this study rather than underlying factors. Proximate variables allow circumventing the lack of reliable purchasing power based on production/productivity statistics for large parts of the world during the $19^{\text {th }}$ and $20^{\text {th }}$ centuries. Many inputs to human welfare were not traded officially but were distributed informally in the form of subsistence farming, intra-household transfers, or black markets. Other goods and services were provided through public goods, such as infant-nutrition programs and public hospitals. Another set of obstacles that economic historians must address are similar to those of contemporary development economists. Even if accurate production statistics are available, the international comparability may be limited due to different baskets of goods, different price indices (e.g., Laspeyres vs. Paasche) or the change in the quality of the goods and services (Nafziger 2012). We address these shortcomings by using outcome-oriented measures.

Similar to average height, proximate determinants can also capture the outcome of economic activities, such as agricultural production and health status, but they do not allow for the direct measuring of nutrition quality or the disease environment. We take into account that the prices of goods and services in two different places at two different points in time may differ, especially if someone applies exchange rates to convert production values in a common currency, as the utility these goods and services provide is independent of time and space. Given this, the regression analyses as performed in this study rely on a number of proximate variables to measure animal protein consumption (cattle, meat and milk availability), biological living standards (average male height) and infant mortality rate (disease environment).

\footnotetext{
${ }^{5}$ The codebook is available at http://www.correlatesofwar.org/COW2\%20Data/WarData_NEW/WarList_NEW.html (last access, January 16th, 2013).
} 


\section{[FIGURE 3 HERE]}

In Figure 3, which was drawn using some interpolation, the results of Baten and Blum (2012a) are shown (in Appendix A, a Figure without interpolation is included). In general, four different types of countries can be identified. First, during the entire period under observation, Anglo-Saxon settlements were characterized by superior biological living standards. Moreover, after the 1880 s, Western Europe, Eastern Europe and Central Asia experienced a substantial upward trend. However, after the foundation of the Soviet Union, discrepancies increased between the West and the East with respect to height (Mironov 2012). Conversely, Latin American and Middle Eastern populations were relatively tall during the $19^{\text {th }}$ century, but they then fell behind in relative terms in the $20^{\text {th }}$ century (Salvatore 2004a).

In addition, East Asia and sub-Saharan Africa remained consistent with the world average during the period under observation, with the exception of East Asia during the late $19^{\text {th }}$ century. Sub-Saharan Africa is the only world region to experience a decline in average heights in absolute terms (Moradi 2005). Finally, the data show that South and Southeast Asia experienced no clear trend in the $19^{\text {th }}$ century, while in the $20^{\text {th }}$ century, Southeast Asia's average height increased constantly, eventually reaching South Asia's average height in the 1980s. South Asia, however, is still characterized by stagnating stature (Brennan, McDonald and Shlomowitz 1994a, 1994b, 1997, 2000, Guntupalli and Baten 2006, Baten, Stegl and van der Eng 2013), a finding that actually corresponds quite well with the population pressure on the agricultural resources that we identified herein (Tables 1 and 2). The pressure on Africa in the late $20^{\text {th }}$ century is visible in both data sets as are the food scarcities in Asia and other world regions during the WWII era.

It is remarkable that some countries have a reputation for a bad disease environment and yet still display tall heights. People are sometimes tall in countries and regions with problematic disease environments - such as the U.S. American South or the African Sahel zone region. The inhabitants of the Southern states, for example, were taller than the Northerners before the Civil War, whereas 
our perception of disease environments suggests that warmer climates, in general, and malariainfected river deltas, in particular, were less healthy than the Northern climates. Similarly, the disease environment of the Sahel zone was most likely quite adverse, compared to European countries, though our knowledge is limited for early periods. However, it seems that, to a certain degree, good local protein availability counter-balances problematic disease environments. For example, values of cattle per capita were extremely high in the Sahel zone, and the population was apparently able to create antibodies. Nevertheless, climatic vulnerability was also high, and even small reductions in rainfall resulted in famine, conflict and death. In the southern U.S., similar compensation phenomena due to protein availability most likely occurred. It is worth noting, however, that the income of the white population in the Southern states was also very high.

\section{Regression analysis: baseline estimates}

In the following analysis, we focus on proximate determinants: protein availability, disease environment and altitude. ${ }^{6}$ In contrast, factors such as productivity, institutional design, income, education, trade, religion and similar variables are considered underlying causes that may determine or contribute to the proximate causes - disease environment and the consumption of high quality foodstuffs. We did not include the underlying but proximate determinants in our analysis. Only civil war, GDP and democracy were included as indirect determinants because we wanted to control for the exceptional situation of civil war, for the potential omitted variable of GDP and for the inequality effects of political autocracy.

We use panel data composed exclusively of actual observations (no interpolations) and check for the existence of unit root problems by considering the residuals of our regression by means of the Fisher test (Maddala and Wu 1999). This results in a chi-square (112) value of 289.98 and a p-value of 0.00. As the null hypothesis of the Fisher test is formulated in such a way that the series is non-stationary, we conclude that there is no unit-root problem. As we also take potential

\footnotetext{
${ }^{6}$ The very first (approximately 3 ) years of life constitute the most important growth period. Therefore, all variables are arranged by birth decades as they capture influences on height around that crucial time.
} 
serial correlation seriously, we cluster standard errors at the country level in every specification.

We include a range of variables to control for the availability of animal protein per capita (Baten 1999, 2009). In a bivariate graphical analysis of the cross-section of the 1900 birth decade, cattle per capita suggests a positive correlation (Figure 4), though there are three modest deviations - Argentina, and to a lesser extent Cuba and Madagascar - as indicated in the lower right of the Figure. Argentina's population may have been deprived of animal protein because the country exported a significant portion of its cattle products, and Cuba and Madagascar displayed similar behaviors, at least during the early $20^{\text {th }}$ century (Salvatore 2004b). ${ }^{7}$

The per capita availability of livestock is a useful protein-related indicator as cattle accounts for a large share of the meat and milk supplies. Accordingly, the effect of cattle per capita is positive and statistically significant (Table 5, Column 1).

[FIGURE 4, TABLE 5 HERE]

This protein indicator is available for a large number of observations, but because it does not account for productivity per animal, we developed a second Model that replaces cattle per capita with the annual output of meat per capita and a third Model that permits us to estimate the amount of milk per capita. As a result, we were able to determine that animal-protein availability has a positive impact on height, as the coefficient's level is consistently significant. We include the infant mortality rates to control for disease environment, and the results confirm our expectations. That is, a problematic disease environment is associated with shorter people, as the one-standard-deviation effect is approximately twice that of the protein effect.

Both protein and disease environment are significant and display the expected signs when assessed separately (Table 5, Columns 4 and 5). The R-squares, however, are somewhat larger in the case of the regression where the only variable is the disease environment. These data should be

\footnotetext{
${ }^{7}$ We experimented with cattle trade share data that may have helped to clarify this issue, but as the data were scanty, the results were not decisive and were therefore not presented.
} 
interpreted with caution because just as average income is only a rough indicator of a population's well-being, cattle per capita is only a rough indicator of protein availability as, due to the pressure of the export market, much of the meat may, in fact, not end up in local markets. Perhaps even more importantly, the output of protein per animal varies.

One factor that is particularly difficult to measure is inequality. Hence, we only include the political variables that may have redistributive effects. In addition, it has been argued that the anthropometric welfare indicator, human stature, by itself is already more sensitive to inequality as heights of the poorer strata tend to be more vulnerable during difficult times (Blum 2013a). Do the findings suggest that the biological standard of living in countries run by non-democratic governments tends to be lower than that of similarly wealthy countries? While the coefficient is positive, the degree is insignificant, thus suggesting that the answer is 'no' (Table 5, Column 2). The same conclusion holds with respect to civil war, at least when all other variables are included.

The proportion of mountainous areas in a given region has been hypothesized to have a direct effect, in anthropological studies, on height, though a consensus has yet to be reached. ${ }^{8}$ For example, Harrison and Schmidt (1989) argue that humans who live at high altitudes (such as the Peruvians in the Andes) tend to be relatively short, thus contradicting previous studies of the Alps, the Scottish Highlands and the French Jura. If Harrison and Schmidt are correct, this effect could be, in part, because the disease environment in such regions benefits from underpopulation. In addition, high-altitude Europeans, in particular, benefit from their proximity to protein production (Baten 1999). Having controlled for protein proximity and disease effect, we side with Harrison and Schmidt, although the effect is minimal. Because mountain dwellers in less developed countries are relatively poor and mountains reduce agricultural productivity and raise infrastructure costs, economic variables likely contribute to this pattern.

If we use standardized coefficients rather than conventional coefficients, the results are

\footnotetext{
${ }^{8}$ A similar geographic factor which has received some attention is the insolation effect (working via vitamin D production in the human body). The literature finding positive effects has mainly focused on single countries so far. Studying it for a number of countries would be a desideratum for the future.
} 
confirmed (Table 6). Standardized coefficients allow us to compare the magnitude of impact of the independent variables on the dependent variable. The results presented in Table 6 suggest that the effect of disease environment, measured by the infant mortality rate, is greater than the effect of cattle per capita, thereby suggesting that the former variable is somewhat more important, at least for the period and countries for which both variables can be observed.

We were also curious whether GDP per capita, as an indicator of the general production capacity of a country, would replace or minimize any positive impacts of protein availability and disease environment. A priori, we expected a lower GDP replacement effect for disease environment given that higher income cannot buy better health (at least not until the medical technology revolutions of the early $20^{\text {th }}$ century). Nonetheless, we would have expected that the GDP could have replaced a substantial part of the protein effect, as proxied by cattle per capita. In Table 6, Models (4) and (5), GDP per capita was included, in one specification, jointly with cattle per capita, and in another, jointly with infant mortality, our disease indicator. In both cases, while the GDP has a positive sign and becomes statistically significant, it does not lead to the insignificance of cattle per capita or infant mortality. Interestingly, the size of the latter declines by approximately $50 \%$, whereas the size of the cattle coefficient declines only by approximately $30 \%$, and the adjusted R-square increases modestly in the case of the cattle-GDP combination (from 0.45 to 0.53 ). Especially during the $20^{\text {th }}$ century, countries with a higher GDP had lower infant mortality and better anthropometric values. A high GDP per capita in combination with a low cattle per capita would impact cattle imports if exporters were available, given the transport technology restraints. A low GDP and a high cattle per capita should provide incentives to become a protein-exporting country. In contrast, however, the adjusted R-square does not increase if the disease environment is complemented by a GDP per capita variable. ${ }^{9}$ We emphasize that we are not arguing for a specific direction of causality when we include GDP, as it might well be that height influences GDP. The inclusion of this variable is only intended to avoid a potential omitted variable bias. We conclude

\footnotetext{
${ }^{9}$ Unfortunately, it is not possible to estimate a more general model including all these variables as the number of cases would become too small.
} 
that while GDP per capita adds some explanatory power (and controls for food imports and exports), it does not completely replace the effect of local protein availability and local disease environment.

\section{Endogeneity}

In principle, we could imagine a problem of reverse causality. In other words, rather than higher local cattle per capita figures resulting in increased height, it may be that people who are financially better-off (and, hence, probably also physically stronger) may be able to maintain a larger number of cattle due to superior productivity. Instrumental variable (IV) techniques allow circumventing this problem, providing a suitable instrument can be found. In addition, IV techniques can serve a second function, namely, to reduce measurement error as cattle per capita is a rough proxy for milk consumption per capita, and thus includes a substantial amount of measurement error. Therefore, applying IV techniques mitigates the severity of the problem.

An attractive instrumental variable is lactose tolerance. Because lactose tolerance is genetic and, hence, generally exogenous during the period under study, the lactose tolerance variable allows us to conduct an endogeneity test of the protein-availability variable. Data on lactose tolerance are taken from Ingram et al. (2009) and Flatz (1995). The data reflect the portion of a population (in \%) that does benefit from lactose tolerance. In some countries, cattle stock and milk production go hand-in-hand, while in other countries, the focus is mainly on meat production. Therefore, the idea behind this variable is to separate the ability to digest milk (or the lactose in milk) and the availability of cattle. In general, the prevalence of lactose tolerance leads to a higher consumption of cow milk compared to estimates based on purchasing power as many people voluntarily renounce cow milk. Children without this limitation have more time to consume milk without being affected by side effects and are therefore able to access the benefits of milk consumption for a longer period of time. While children usually lose lactose tolerance after the weaning phase, Sahi (1994) contends that the period until a child becomes intolerant to lactose can vary considerably 
between populations.

One of the major challenges in any instrumental variable approach is the requirement of the exclusion restriction, which implies that the instrumental variable does not have a direct influence on the ultimate dependent variable except via the instrumental variable. However, in the case of lactose tolerance, it is clear that any effect on height requires a certain amount of milk production; otherwise, an effect cannot be imagined. Hence, in this case, the exclusion restriction is not violated.

When instrumenting cattle per capita with lactose tolerance, we obtain a significantly positive coefficient, one that is even larger than the aforementioned cattle coefficients (Table 7), thus indicating that the IV result is most likely estimated with less measurement error. The first stage results indicate that lactose tolerance could be an instrument for the potentially endogenous variable cattle per capita. However, with an F-statistic of less than 10, it is a weak instrument and therefore requires a limited information maximum likelihood (LIML) estimation technique. The results of this estimation approach are identical to the IV estimates.

[TABLE 6, 7 AND 8 HERE]

The coefficients of disease environment and GDP are insignificant in the regressions. It should not be concluded from this result that the disease environment and production capacity are less relevant. ${ }^{10}$

\footnotetext{
${ }^{10}$ In the case of the GDP, we stressed that it is included herein, though we do not argue for one direction of causality. We would prefer instrumenting also infant mortality; however, unfortunately, an instrumental variable for infant mortality for such an early period is not available, because it is also not strongly exogenous, even if is has a reputation for being more exogenous than child mortality (which is more nutrition-related). A large part of infant mortality in contrast is related to hygienice and breast-feeding behaviour, as well as the disease environment. As we cannot instrument infant mortality, we will not interpret this part of the analysis as causal. For example, we would not interpret the insignificance of infant mortality once protein proximity is instrumented. As we consider the assessment of the proximity effect as the more relevant contribution of this article, we decided to use this IV regression, even if only one of the two variables could be instrumented.
} 


\section{Early and late developments}

Due to a sufficient number of observations, we were able to distinguish an early (1870 to 1949) and a late (1950 to 1989) period (Table 9). ${ }^{11}$ We expect to find a decline in the importance of local protein production and health advantages during the late period due to technological developments, such as refrigeration and other storage methods, that permit an expansion of the international market in both foodstuffs and medical materials.

We find that between 1870 and 1949 both the country-specific output of protein and our disease proxy had fairly large coefficients, thus indicating that the effect was greater for that period than it was between 1950 and 1989, when, in fact, the coefficients for disease and protein had diminished (Table 8, Column 3).

When comparing standard deviation (SD) effects, we find that one SD during the early period $(\mathrm{SD}=1.10)$ accounts for an additional $1.51 \mathrm{~cm}$ in height, whereas for the latter period, with a standard deviation for cattle of 1.04 , the effect is only 0.63 . We interpret this change as a gradual change from protein proximity to income and other factors (such as public health) over time as determinants of biological welfare. As a caveat to our argument that the explanatory share of protein availability declined, we note that protein sources may also have changed substantially as, for example, the composition of types of meat may have changed.

\section{A lower-bound estimate of the effects of food behavior, intergenerational effects, culture, and other currently unobservable factors}

We also include a full set of birth-decade and world region dummies in most of the aforementioned regressions. The comparison of the world region dummies in regressions with and without explanatory variables permits us to estimate the size of various unobservable characteristics. While the early generations of anthropologists firmly believed in the existence of races (a term later replaced by genetic potential), there is, today, a consensus among leaders in the field that height

\footnotetext{
${ }^{11}$ As for the early period, 1810-70, there were an insufficient number of countries providing all of the explanatory variables to permit accurate analysis.
} 
potential is primarily a function of environmental factors (Bogin 1988).

Second, human preferences and behaviors related to food may play a role, especially in rich industrial societies where the consumption of red meat and other protein-rich foodstuffs seems to have stagnated or declined. Food taboos, however, also exist in poor countries and have supposedly caused some ethnicities and religious groups to consume less protein than they otherwise would have. Two of the most famous religious taboos include the Hindu's ban on beef and the Muslim's ban on pork. However, the question is whether these taboos would have a substantial effect given that substitution of other protein sources may be possible. However, recent evidence has shown that the influences are limited and should only be taken into account if countries with strongly opposed dietary patterns are being compared (Blum 2013b).

The third possible factor is that of intergenerational size limits. In this regard, Cole (2003) has argued that Japanese height levels could not quickly catch up with Western height levels because of a biological check mechanism on the size of a baby relative to that of the mother. In other words, the body prevents the fetus from growing too large if the birth channel of the mother is not as large. Another intergenerational factor may be dietary habits. For example, dietary habits of migrants may persist in a second generation even after moving to a new environment with different relative prices. Accordingly, the offspring of those who have migrated from low-protein to highprotein regions may continue to eat the low-protein dishes favored by their parents.

\section{[TABLE 9 HERE]}

These and some other potential unobservable factors should be reflected in the regressions of world region dummy variables after the effect of observable explanatory variables has been removed. Therefore, we compare two such sets of regressions, one with and the other without explanatory variables controlling for environmental factors. While Western Europe is the constant, among the other world regions, there is a sharp decline in the coefficients that capture world region 
specific effects when all explanatory variables are included. For example, when differences in cattle per capita and similar factors are not controlled, the average height of East Asians is lower by 8.2 $\mathrm{cm}$, but when these factors are controlled, the difference is only $4 \mathrm{~cm}$. We should note that because measurement error produces a downward bias to coefficient size, the shrinkage of the coefficient may yield a lower-bound estimate of the effect of explanatory variables. Similarly, the coefficients of Latin America, South Asia and Africa decreased by approximately 50\%, while the decrease in the coefficient of Southeast Asia was somewhat less. When explanatory variables are controlled, the Middle East and Eastern European coefficients diminished to the point of insignificance. The region comprising North America, Australia and New Zealand was characterized by a positive coefficient relative to that of Western Europe.

\section{Conclusion}

During the $19^{\text {th }}$ and $20^{\text {th }}$ centuries, agriculture in many countries succeeded in feeding a growing population better than it had in earlier times, and its efficiency gains enabled large parts of a formerly agricultural labor force to be active in other sectors. However, before we agree to this broadly accepted judgment, the findings presented in this study must be considered. The analysis in this paper links agricultural production levels and human consumption on a global scale during the past two centuries.

We use average height from a global panel of countries as a proxy for human well-being, which allows us to investigate welfare from a nutritional perspective. We also consider the remarkable differences in world regions as height has not increased substantially in all countries. For example, Europeans are tall today while South Asians remain short. We confirm that the major determinants of biological well-being and, hence, height are the quality of nutrition and the disease environment, whereas geography is a minor determinant. As animal protein production plays a crucial role in determining human health and welfare, economies that were able to invest in a high 
share of cattle and dairying achieved the most advanced levels of welfare and development. In addition, we find that lactose tolerance influences biological living standards through milk consumption, a somewhat neglected issue in the anthropometric literature. Moreover, our results suggest that influences other than environmental ones play only a small role in the determination of average height. The size of world region coefficients decrease significantly when including variables that capture environmental factors, such as diseases, quality of nutrition and political and geographical variables. A series of robustness tests, such as IV regressions where lactose tolerance is used as an instrument for cattle availability, confirms these findings.

In addition, the results presented in this study may contribute to understanding the wider development of living standards during the past two centuries. Until the mid-20 $0^{\text {th }}$ century, the local availability of cattle per capita and the disease environment mainly determined the stature of the population. During the late $20^{\text {th }}$ century, trade increased and other factors became more important. This also implied that the local protein availability was crucial for the health and life expectancy of early populations. Robert F. Fogel (1993) stressed, in his lecture to the Nobel Prize committee, that a height gap of $17.5 \mathrm{~cm}$ for modern Norwegian males in the 1960s and 1970s meant a higher probability of dying in the following period of not less than $71 \%$, clearly a significant amount. He based his work on Waaler (1984), who measured several thousands of Norwegians and followed them in a longitudinal study. Norway had one of the populations with the best nutrition in the late $20^{\text {th }}$ century. Baten and Komlos (1998) estimated that one additional centimeter in height equals approximately 1.2 years additional life expectancy, with only a negligible coefficient change over time among the birth cohorts of 1860, 1900 and 1950, i.e., the latter being adults in the 1970s to the present. Hence, $1 \mathrm{~cm}$ is clearly a meaningful amount as living 1.2 years, more or less, is a substantial asset in the quality-of-life portfolio. 


\section{References}

BATEN, J. (1999). Ernährung und wirtschaftliche Entwicklung in Bayern, 1730-1880 [Nutrition and Economic Development in Bavaria, 1730-1880]. Stuttgart: Steiner.

BAtEN, J. (2009). Protein supply and nutritional status in nineteenth century Bavaria, Prussia and France. Economics and Human Biology 7 (2), 165-180.

BATEN, J. and KomlOS, J. (1998). Height and the standard of living. Journal of Economic History 57(3), 866-870.

BATEN, J. and BLUM, M. (2012a). Growing Tall but unequal: new findings and new background evidence on anthropometric welfare in 156 countries, 1810-1989. Economic History of Developing Regions 27(1), 66-85.

BATEN, J. and BLUM, M. (2012b). An anthropometric history of the world, 1810-1980: did migration and globalization influence country trends? Journal of Anthropological Sciences 90, 1-4.

BAten, J., Pelger, I., and Twrdek, L. (2009). The anthropometric history of Brazil, Lima (Peru), and Argentina during the 19th and early 20th century. Economics and Human Biology 7-4, 319-333.

BAten, J., STEgl, M. and VAN DER EnG, P. (2013). The biological standard of living and body height in colonial and post-colonial Indonesia, 1770-2000. Journal of Bioeconomics 15(2), 103-122.

BLuM, M. (2011). Government decisions before and during the First World War and the living standards in Germany during a drastic natural experiment. Explorations in Economic History 48(4), 556-567.

BLUM, M. (2013a). The influence of inequality on the standard of living: worldwide anthropometric evidence from the 19 th and 20th centuries. Economics and Human Biology 11(4), 436-452.

BLum, M. (2013b). Cultural and genetic influences on the "Biological Standard of Living". Historical Methods 46(1), 19-30.

Bogin, B. (1988). Patterns of Human Growth. Cambridge: Cambridge University Press.

BoGIN, B. and KEEP, R. (1998). Eight thousand years of human growth in Latin America: economic and political history revealed by anthropometry. In J. KOMLOS AND J. BATEN (eds): The Biological Standard of Living in Comparative Perspective, Stuttgart: Steiner.

Brennan, L., MCDOnALD, J. and Shlomowitz, R. (1994a). The heights and economic wellbeing of North Indians under British rule. Social Science History 18, 271-307.

Brennan, L., MCDonald, J. and Shlomowitz, R. (1994b). Trends in the economic well-being of South Indians under British rule: the anthropometric evidence. Explorations in Economic History 31, 225-260.

Brennan, L., MCDOnAld, J. and SHLOMOwitz, R. (1997). Towards an anthropometric history of Indian under British rule. Research in Economic History 17, 185-246.

Brennan, L., McDonald, J. and Shlomowitz, R. (2000). Change in the stature of North Indians from British rule. Jahrbuch für Wirtschaftsgeschichte, 129-148.

Cameron, A.C., Trivedi, P.K., 2009. Microeconometrics Using Stata. Stata Press, College Station TX.

ChesnaIS, J-C. La Transition Demographique. PUF, Paris 1986.

Clark, G. (2007). Farewell to Alms: A Brief Economic History of the World. Princeton.

COLE, T.J. (2003). The secular trend in human physical growth: a biological view. Economics and Human Biology 1, $161-168$.

COLLIER, P. and A. HOEFFLER (2004). Greed and grievance in civil war. Oxford Economic Papers. 56(4): 563-595

Collver, O. A. (1965). Birth Rates in Latin America: New Estimates of Historical Trends and Fluctuations. Berkeley, California: Univ. of Calif., Inst. of Internat. Studies.

CRAFTS, N. (2002). The human development index, 1870-1999: some revised estimates', European Review of Economic History 6(3), 395-405.

DE BEER, H. (2012). Dairy products and physical stature: A systematic review and meta-analysis of controlled trials Economics and Human Biology 10(3), 299-309.

DuRLAUf, S.N., JOHNSON, P.A. and TEMPLE J.R.W. (2004). Growth Econometrics. Working paper, University of Wisconsin.

EASTERLIN, R.A. (1999). How beneficient is the market? A look at modern history of mortality, European Review of Economic History 3, 257-94.

FAO Statistical Database; available at www.fao.org.

FEDERICO, G. (2004). The growth of world agricultural production, 1800-1938. Research in Economic History 22, 12582.

FEDERICO, G. (2005). Feeding the World: An Economic History of Agriculture, 1800-2000. Princeton: Princeton University Press.

FLATZ, G. (1995). The genetic polymorphism of intestinal lactase activity in adult humans. In Scriver CR, Beaudet AL, Sly WS, Valle D (eds.): The Metabolic and Molecular Bases of Inherited Disease. III, $7^{\text {th }}$ ed. New York: McGrawHill, 441-4450, 1995.

Floud, R., Fogel, R., HARris, B. and Hong, S.C. (2011). The Changing Body: Health, Nutrition and Human Development in the Western World since 1700, Cambridge University Press, Cambridge.

Fogel, R.W., ENGERMAN, S.L., and J. TRUSSELl (1982). Exploring the uses of data on height: the analysis of long-term trends in nutrition, labor welfare, and labor productivity. Social Science History 6, 401-421.

GRIGG, D. (1995). The pattern of world protein consumption, Geoforum 26 (1), 1-17 
Guntupalli, A.M. and BATEN, J. (2006). The development and inequality of heights in North, West and East India, 1915-44. Explorations in Economic History 43 (4): 578-608.

HAINES, M.R., L.A. CRAIG, T. WEISS (2003). The short and the dead: nutrition, mortality, and the "Antebellum Puzzle" in the United States. The Journal of Economic History 63(2), 382-413.

HARRISON, G.A. and L.H. SCHMitT (1989). Variability in stature growth. Annals of Human Biology 16, 45-51.

HATTON, T. (2013). How have Europeans grown so tall? Oxford Economic Papers (forthcoming, advance access).

HÜBNER, H. (several years). Hübner's geographisch-statistische Tabellen aller Länder dieser Erde. Wien: Seidel

INGRAM, C.J.E. et al. (2009). Lactose digestion and the evolutionary genetics of lactase persistence, Human Genetics 124, 579-591.

KomLOS, J. (1985). Stature and nutrition in the Habsburg monarchy: the standard of living and economic development in the eighteenth century. American Historical Review 90 (5), 1149-61.

KomLOS, J. (1987). The height and weight of West Point cadets: dietary change in antebellum America. The Journal of Economic History 47(4), 897-927.

KomLOS, J. (1998). Shrinking in a growing economy? The mystery of physical stature during the industrial revolution. The Journal of Economic History 58, 778-95.

KOMLOS, J. and BATEN, J. (2004). Looking backward and looking forward: anthropometric research and the development of social science history. Social Science History, 1-24.

Komlos, J., and BATEN, J. (1998). The Biological Standard of Living in Comparative Perspective. Stuttgart 1998.

KoPCZYNSKI, M. (2006). Agrarian reforms, agrarian crisis and the biological standard of living in Poland, 1844-1892. Economics and Human Biology 5 (3), 458-470.

MADDALA, G.S. and Wu, S. (1999). A comparative study of unit root tests with panel data and a new simple test. Oxford Bulletin of Economics and Statistics 61, 631-652.

MAdDISON, A. (2001). The World Economy: A Millennial Perspective. OECD, Paris.

MARGO, R. and R.H. STECKEL (1983). Heights of native born Northern whites during the antebellum period. Journal of Economic History 43, 167-74.

MARShALL, Monty G., and Q, K.(2008). Polity IV Project: data set. last accessed March 31 2010.

MironOV, B.N. (2006). Data Set on Russian Heights, provided by email. See also Mironov 2004, 2008.

MIRONOV, B.N. (2012). The Standard of Living and Revolutions in Imperial Russia, 1700-1917. Routledge Explorations in Economic History

MitCHELL, B.R. (1980) International Historical Statistics. European Historical Statistics 1750-1975. London: MacMillan.

MitCHELL, B.R. (1983). International Historical Statistics. Africa and Asia. London: Macmillan.

Mitchell, B.R. (1983). International Historical Statistics. The Americas and Australasia. London: Macmillan.

Moradi, A. (2005). Height, Political Violence and Economic Development in Africa 1950-2000, Ph.D. thesis Tuebingen, available on University Library Tuebingen server.

NAFZIGER, E.W. (2012). Economic Development. $5^{\text {th }}$ Edition, Cambridge University Press

PRAdOS DE la EscosurA, L. (2010). Improving Human Development: A Long-Run View. CEPR Discussion Paper 7982.

PRESTON, S.H. (1975). The changing relation between mortality and the level of economic development, Population Studies 29, 231-48.

SAHI, T. (1994). Genetics and epidemiology of adult-type hypolactasia. Scandinavian Journal of Gastroenterology 29(202), 7-20.

SALVATORE, R. (2004a). Stature, nutrition, and regional convergence: the Argentine northwest in the twentieth century. Social Science History 28-2, 231-248.

SALVATORE, R. (2004b). Stature decline and recovery in a food-rich export economy: Argentina 1900-1934. Explorations in Economic History 41(3), 233-255.

Singer, J.D. and M. SMALl (1972). The Wages of War, 1816-1965: A Statistical Handbook. New York. Or see http://www.correlatesofwar.org last accessed March 31 st 2010. http://www.systemicpeace.org/polity/polity4.htm\#top

STECKEL, R. (1995). Stature and the standard of living. Journal of Economic Literature, 1903-40.

STECKEL, R. (2009). Heights and human welfare: recent developments and new directions. Explorations in Economic History 46, 1-23.

STEGL, M. and J. BATEN (2009). Tall and shrinking muslims, short and growing Europeans: an anthropometric history of the Middle East, 1840-2007. Explorations in Economic History 46 (2009), 132-148.

TWRDEK, L. and K. MANZEL (2010). The seed of abundance and misery: Peruvian living standards from the early republican period to the end of the guano era (1820-1880). Economics and Human Biology 8 (2), 145-152.

WAALER, HANS T. (1984). Height, weight, and mortality: the Norwegian experience, Acta Med Scand. 1 (56), supplement 679.

WORLD BANK. Development Indicators (1994-1995), Washington, DC: Bank.

ZEHETMAYER, M. (2011). The continuation of the antebellum puzzle: stature in the US, 1847-1894. European Review of Economic History 15(2), 313-327. 


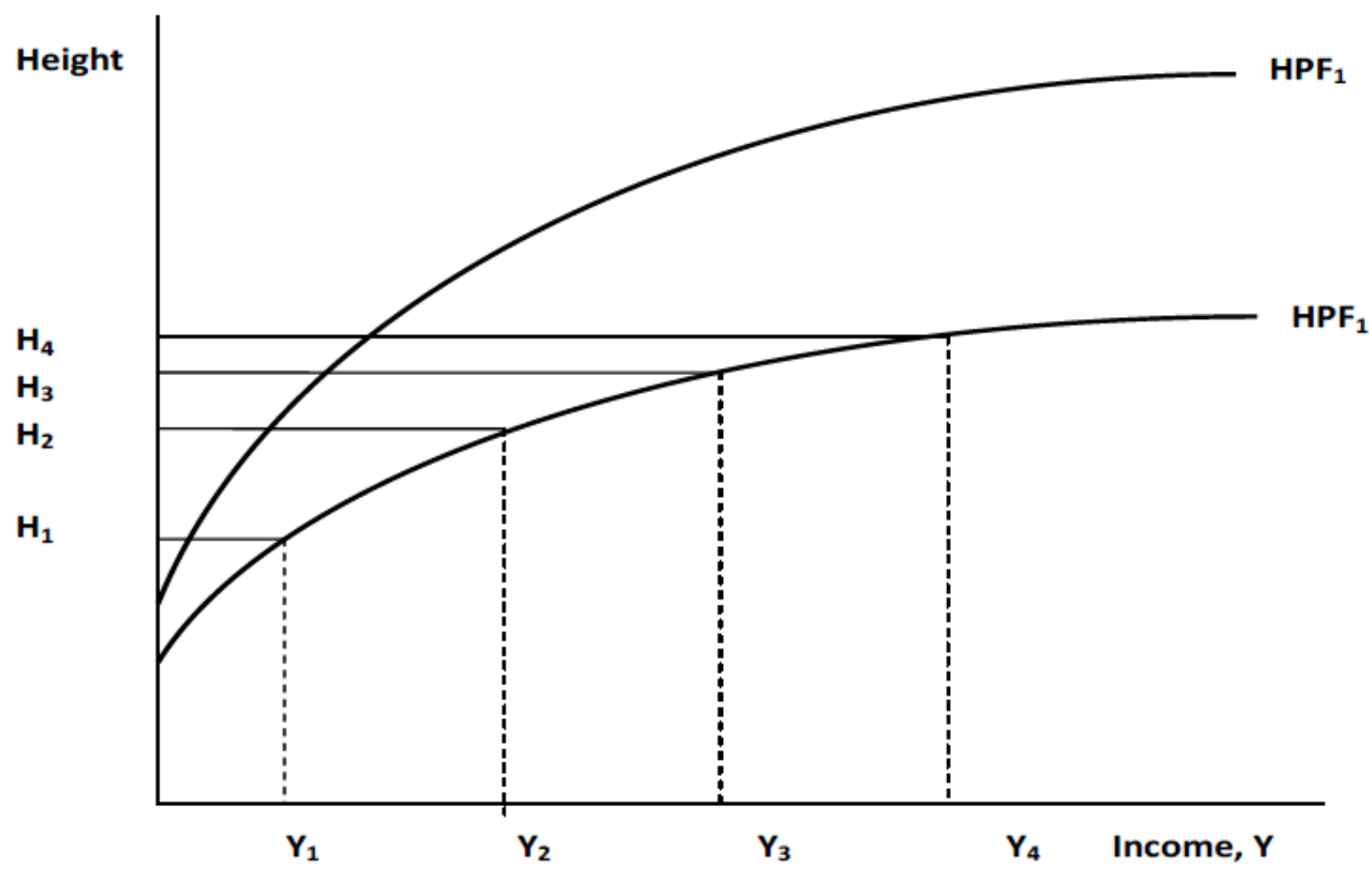

Figure 1. The health production function .

Source: Hatton (2013). 


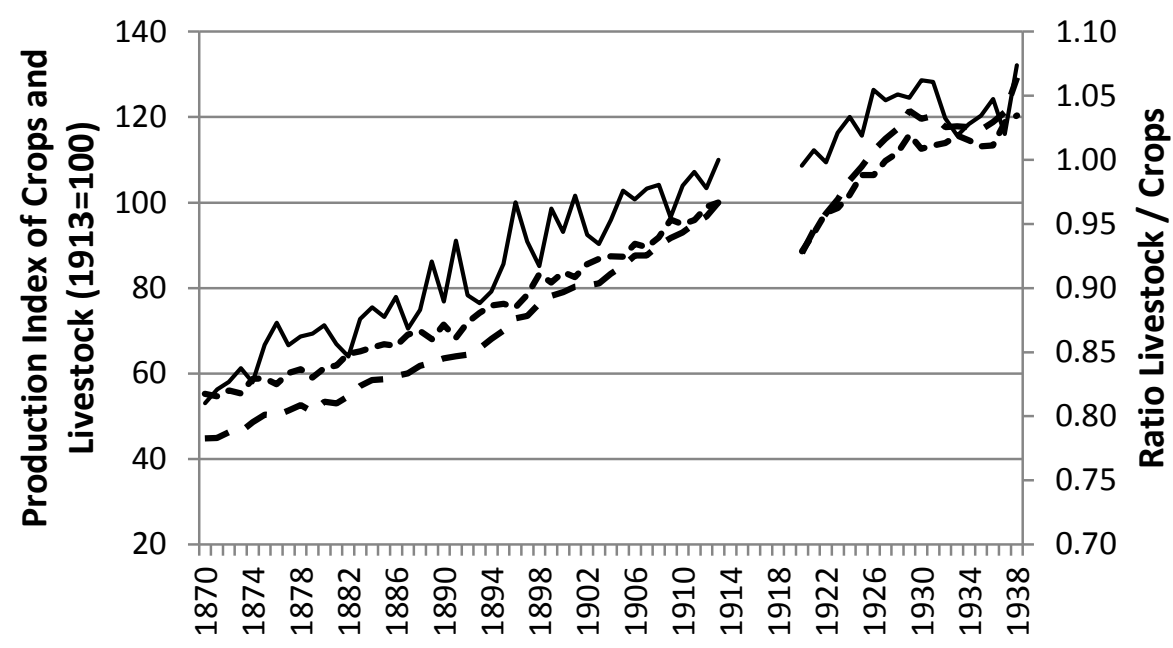

---Crops - - Livestock Ratio Livestock / Crops

Figure 2. Production levels of crops and livestock and the composition of production. Data source: Federico (2004, 2005). 


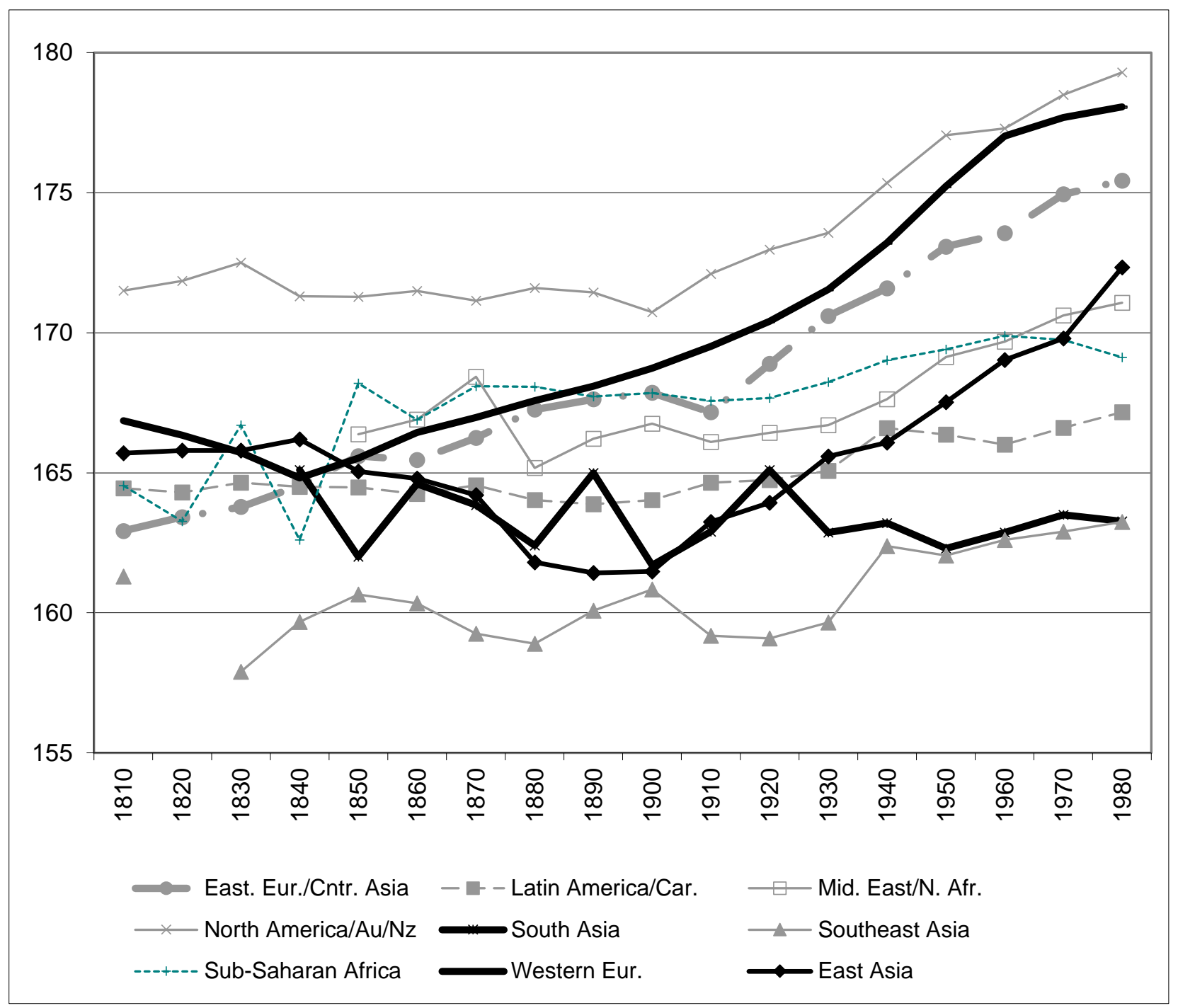

Figure 3. Height trend by world region (using interpolations, weighted by population size). Notes: Migrant heights are included (but account only for $0.7 \%$ of the sample). Source: Baten and Blum (2012a). See ther Tables 1 and 9 for data coverage by country. Note: The standard world region classification has been used. The only exception is a group of 4 former British settler colonies (US, Canada, Australia \& New Zealand) as they experienced a great share of Western European settlers and are characterized by land abundance which allowed superior nutrition and eventually qualified them to become food exporters in the first wave of globalization (Baten and Blum 2012b). 


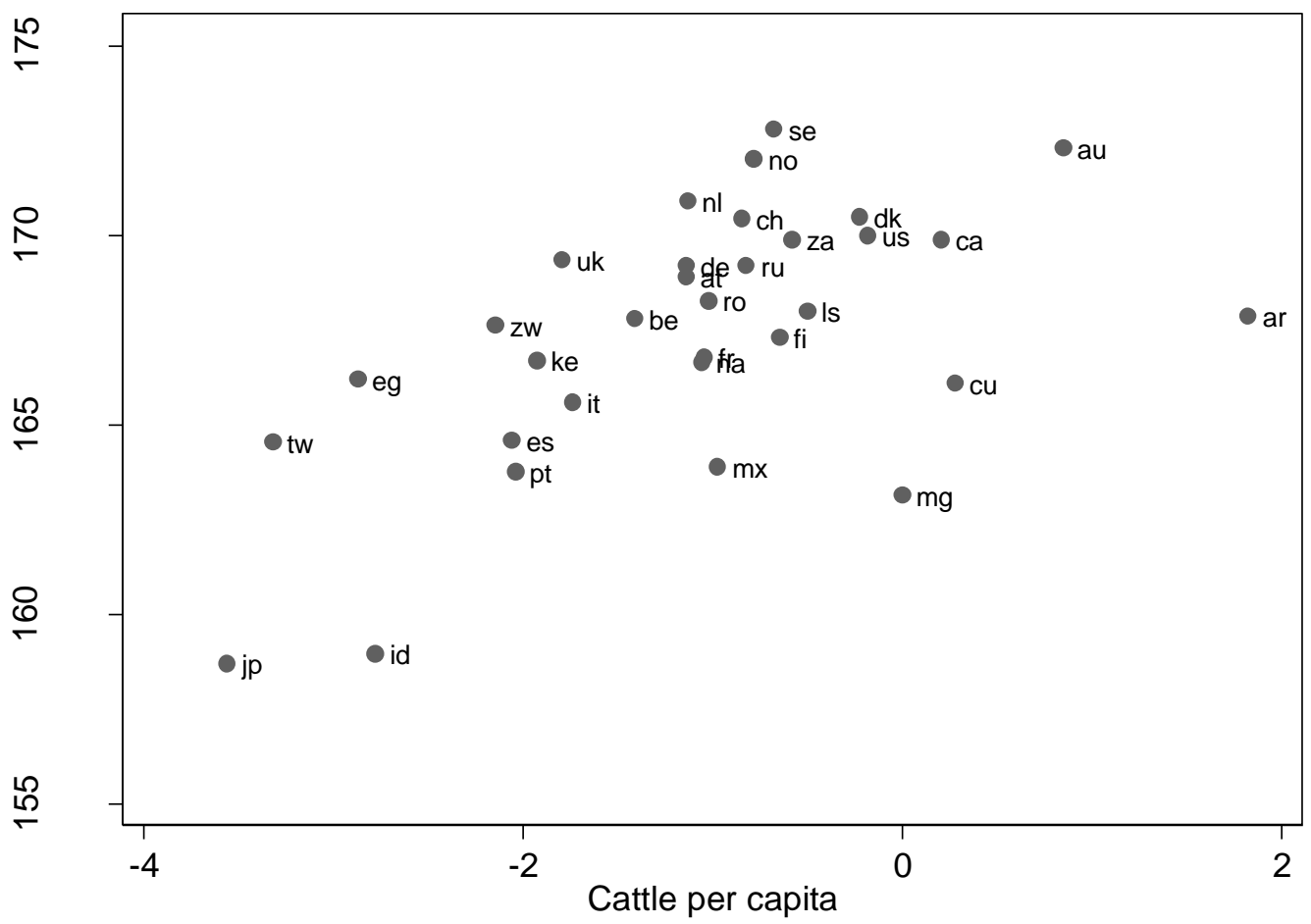

Figure 4. Correlation between (In) cattle per capita and height in 1900

Source: see text. Country abbreviations are ISO-2-character abbreviations (see table 3). 
Table 1. Rates of change in gross agricultural output and population growth, 1870-1938

\begin{tabular}{lrrrrrr}
\hline \hline & & & & $1870-$ & $1870-$ & $1913-$ \\
& $1870-1938$ & $1870-1913$ & $1913-1938$ & 1938 & 1913 & 1938 \\
\hline North Western Europe & Agric.O. & Agric.O. & Agric.O. & Pop. & Pop. & Pop. \\
Southern Europe & 0.97 & 1.02 & 1.50 & 0.62 & 0.84 & 0.29 \\
Eastern Europe & 0.89 & 0.81 & 1.19 & 0.69 & 0.67 & 0.76 \\
Asia & 1.67 & 2.13 & $\mathbf{0 . 3 6}$ & 0.96 & 1.20 & 0.59 \\
South America & 0.97 & 1.11 & $\mathbf{0 . 5 8}$ & 0.70 & 0.60 & 0.89 \\
Western Settlement & 3.80 & 4.43 & 3.05 & 2.48 & 2.64 & 2.33 \\
World & $\mathbf{1 . 3 7}$ & 2.20 & $\mathbf{0 . 7 4}$ & 1.83 & 2.13 & 1.40 \\
\hline \hline
\end{tabular}

Note: Bold are cases, in which agricultural output grew less than population. Northwestern Europe: UK, France

Sweden, Denmark, Belgium, the Netherlands, Germany, Finland, Switzerland. Southern Europe: Italy, Greece, Spain, Portugal. Eastern Europe: Austria-Hungary and Russia. Asia: Japan, India, Indonesia. Western Settlement: Canada, Australia, USA. South America: Argentina, Uruguay, Chile. ${ }^{\circ}$ not significantly different from zero. Source: Federico (2004, 2005). Maddison (2001), for the population growth figures. 
Table 2. Rate of change in gross agricultural output and population growth, 1938-2000

\begin{tabular}{lrrrrrr}
\hline & $1936 / 38-$ & $1948 / 52-$ & & & & $1960-$ \\
& $1948 / 52$ & $1958 / 60$ & $1961-2000$ & $1935-1950$ & $1950-1960$ & 2000 \\
\hline & Agric.O. & Agric.O. & Agric.O. & Pop. & Pop. & Pop. \\
Africa & 1.72 & 3.10 & $\mathbf{2 . 2 5}$ & 1.10 & 2.43 & 2.69 \\
North Central America & 2.63 & $\mathbf{1 . 4 0}$ & 1.77 & 1.56 & 2.27 & 1.51 \\
South America & 1.68 & 3.13 & 2.92 & 2.30 & 2.99 & 2.19 \\
Asia (excluding China) & $\mathbf{0 . 3 1}$ & 3.64 & & 0.73 & 2.17 & \\
Asia (including China) & & & 3.54 & & & 1.91 \\
Western Europe & 0.56 & 2.55 & 0.91 & 0.49 & 0.77 & 0.46 \\
Oceania & $\mathbf{0 . 8 1}$ & 2.85 & 1.68 & 1.47 & 2.52 & 1.53 \\
USSR/successor states & & & $\mathbf{- 1 . 9 4}$ & 0.00 & 1.96 & 0.79 \\
\hline \hline
\end{tabular}

Note: Bold are cases, in which agricultural output grew less than population. Column (1): from prewar (1936-38) to 1948-52 - compound rates. Column (2): from 1948-52 to 1958-60 - compound rates. Column (c): 1961-2000. ${ }^{\circ}$ not significantly different from zero. Population for Oceania refers to Australia and New Zealand. Source: Federico (2005) based on FAO Statistical Database. Maddison (2001), for the population growth figures. 
Table 3. Number of birth decades documented by country

\begin{tabular}{|c|c|c|c|}
\hline Country & $\mathrm{N}$ Country & $\mathrm{N}$ Country & $\mathrm{N}$ \\
\hline Afghanistan (af) & 3Germany (de) & 18Norway (no) & 18 \\
\hline Albania (al) & 3Ghana (gh) & 13Oman (om) & 0 \\
\hline Algeria (dz) & 3 Greece $(\mathrm{gr})$ & 10Pakistan (pk) & 8 \\
\hline Angola (ao) & 7 Guatemala (gt) & 8Palestinian Territory (ps) & 0 \\
\hline Argentina (ar) & 15 Guinea (gn) & 10Panama (pa) & 1 \\
\hline Armenia (am) & 9Guinea-Bissau (gw) & 8Papua New Guinea (pg) & 5 \\
\hline Australia (au) & 10Guyana (gy) & 5Paraguay (py) & 2 \\
\hline Austria (at) & 14Haiti (ht) & 6Peru (pe) & 14 \\
\hline Azerbaijan (az) & 6Honduras (hn) & 4Philippines (ph) & 8 \\
\hline Bahrain (bh) & 0Hong Kong (hk) & 2Poland (pl) & 12 \\
\hline Bangladesh (bd) & 7Hungary (hu) & 11 Portugal $(\mathrm{pt})$ & 18 \\
\hline Belarus (by) & 3 India (in) & 14Puerto Rico (pr) & 5 \\
\hline Belgium (be) & 10Indonesia (id) & 16Qatar (qa) & 0 \\
\hline Benin (bj) & 8 Iran (ir) & 11Reunion (re) & 0 \\
\hline Bolivia (bo) & 8 Iraq (iq) & 4Romania (ro) & 7 \\
\hline Bosnia and Herzegovina (ba) & OIreland (ei) & 14Russian Federation (ru) & 18 \\
\hline Botswana (bw) & 2Israel (il) & 4Rwanda (rw) & 7 \\
\hline Brazil (br) & 18Italy (it) & 18Saudi Arabia (sa) & 4 \\
\hline Bulgaria (bg) & 4Jamaica (jm) & 6Senegal (sn) & 13 \\
\hline Burkina Faso (bf) & 16Japan (jp) & 11 Serbia and Montenegro (cs) & 5 \\
\hline Burundi (bi) & 2Jordan (jo) & 5 Sierra Leone $(\mathrm{sl})$ & 8 \\
\hline Cambodia (kh) & 14Kazakhstan (kz) & 11 Singapore (sg) & 1 \\
\hline Cameroon $(\mathrm{cm})$ & 13 Kenya (ke) & 9Slovakia (sk) & 7 \\
\hline Canada (ca) & 18 Korea (North) (kp) & 9Slovenia (si) & 4 \\
\hline Cape Verde (cv) & 0Korea (South) (kr) & 9Somalia (so) & 6 \\
\hline Central African Republic (cf) & 8 Kuwait (kw) & 0South Africa (za) & 10 \\
\hline Chad (td) & 10Kyrgyzstan $(\mathrm{kg})$ & 9Spain (es) & 16 \\
\hline Chile (cl) & 2Laos (la) & 11Sri Lanka (lk) & 3 \\
\hline China (cn) & 18Latvia (lv) & 5Sudan (sd) & 7 \\
\hline Colombia (co) & 12Lebanon (lb) & 5Swaziland (sz) & 5 \\
\hline Comoros (km) & 3Lesotho (ls) & 5Sweden (se) & 16 \\
\hline Congo (cg) & 10Liberia (lr) & 7 Switzerland (ch) & 9 \\
\hline Costa Rica (cr) & 2Libya (ly) & 2Syria (sy) & 5 \\
\hline Cote D'Ivoire (Ivory Coast) (ci) & 13Lithuania (lt) & 2Taiwan (tw) & 13 \\
\hline Croatia (Hrvatska) (hr) & 12Macedonia (mk) & 4Tajikistan $(\mathrm{tj})$ & 6 \\
\hline Cuba (cu) & 7Madagascar (mg) & 8Tanzania (tz) & 11 \\
\hline Cyprus (cy) & 4Malawi (mw) & 8Thailand (th) & 8 \\
\hline Czech Republic (cz) & 16Malaysia (my) & 6Togo $(\operatorname{tg})$ & 7 \\
\hline Democratic Republic of the Congo (cd) & 11Mali (ml) & 12 Trinidad and Tobago $(\mathrm{tt})$ & 1 \\
\hline Denmark (dk) & 16Mauritania $(\mathrm{mr})$ & 4Tunisia (tn) & 2 \\
\hline Djibouti (dj) & $\begin{array}{l}\text { 0Mauritius }(\mathrm{mu}) \\
\text { Mayotte, Saint Helena, West Sahara }\end{array}$ & 0Turkey (tr) & 13 \\
\hline Dominican Republic (do) & 4(ytsheh) & 0Turkmenistan (tm) & 3 \\
\hline East Timor (tp) & $1 \operatorname{Mexico}(\mathrm{mx})$ & 17Uganda (ug) & 10 \\
\hline Ecuador (ec) & 0Moldova (md) & 5 Ukraine (ua) & 6 \\
\hline Egypt (eg) & 12Mongolia (mn) & 2United Arab Emirates (ae) & 0 \\
\hline El Salvador (sv) & 0Morocco $(\mathrm{ma})$ & 6United Kingdom (uk) & 18 \\
\hline Equatorial Guinea (gq) & 1 Mozambique (mz) & 10United States (us) & 17 \\
\hline Eritrea (er) & 3Myanmar (mm) & 9Uruguay (uy) & 2 \\
\hline Estonia (ee) & 8 Namibia (na) & 7Uzbekistan (uz) & 8 \\
\hline Ethiopia (et) & 10Nepal (np) & 8 Venezuela (ve) & 6 \\
\hline
\end{tabular}




\begin{tabular}{lllr}
\hline Finland (fi) & 13Netherlands (nl) & 18Viet Nam (vn) & 12 \\
France (fr) & 18New Zealand (Aotearoa) (nz) & 5 Yemen (ye) & 6 \\
Gabon (ga) & 7Nicaragua (ni) & 4Zambia (zm) & 5 \\
Gambia (gm) & 1 Niger (ne) & 11Zimbabwe (zw) & 6 \\
Georgia (ge) & 3Nigeria (ng) & 12 & \\
\hline
\end{tabular}

Note: Migrant heights (unadjusted) were included on the following countries in this Table, but not in the following Tables and Figures, except where noted (in parentheses the number of birth decades: Algeria (2), Armenia(1), Bangladesh (4), Croatia (Hrvatska) (1), Czech Republic (1), India (6), Israel (1), Korea (North) (6), Malawi (1), Mozambique (1), Pakistan (1), Poland (2), Romania (1). 
Table 4. Descriptive statistics (cases included as in Model 1 of Table 5, except milk and meat)

\begin{tabular}{lrrrrr}
\hline \hline Variable & $\mathrm{N}$ & Mean & Std.dev. & Min. & Max. \\
\hline Height & 417 & 169.45 & 4.60 & 156.00 & 182.30 \\
Cattle (p.c.) & 417 & 0.62 & 0.91 & 0.01 & 8.49 \\
Cattle (p.c., ln) & 417 & -1.03 & 1.07 & -4.93 & 2.14 \\
Infant mortality (p.c.) & 417 & 116.85 & 63.63 & 5.80 & 316.10 \\
Infant mortality (p.c., ln) & 417 & 4.55 & 0.75 & 1.76 & 5.76 \\
Democracy & 414 & 6.21 & 3.84 & 0 & 10 \\
Mountain share & 417 & 17.38 & 19.09 & 0 & 82.2 \\
Civil war & 417 & 0.04 & 0.20 & 0 & 1 \\
Meat (p.c.) & 212 & 37.87 & 42.83 & 0.79 & 288.28 \\
Meat (p.c., ln) & 212 & 3.15 & 1.02 & -0.23 & 5.66 \\
Milk (p.c.) & 192 & 291.78 & 343.51 & 0.17 & 2827.86 \\
Milk (p.c., ln) & 192 & 4.87 & 1.63 & -1.76 & 7.95 \\
Lactose tolerance & 296 & 0.59 & 0.31 & 0 & 1 \\
Eastern Europe/ Central Asia & 417 & 0.06 & 0.24 & 0 & 1 \\
Latin America/Caribbean & 417 & 0.17 & 0.38 & 0 & 1 \\
Middle East/North Africa & 417 & 0.04 & 0.19 & 0 & 1 \\
& & & & & \\
North America, Australia, New Zealand & 417 & 0.08 & 0.27 & 0 & 1 \\
Sub-Saharan Africa & 417 & 0.18 & 0.39 & 0 & 1 \\
East Asia & 417 & 0.05 & 0.21 & 0 & 1 \\
South Asia & 417 & 0.01 & 0.05 & 0 & 1 \\
Southeast Asia & 417 & 0.02 & 0.15 & 0 & 1 \\
\hline \hline
\end{tabular}

Note: "East. Eur./Cntr. Asia"= Eastern Europe and formerly members of the Soviet Union. Democracy is a time-invariant variable here that takes the average of all available democracy values for a given country (otherwise the number of cases would be severyly reduced by missing values of this variable that is not really of central importance here). 
Table 5. Determinants of height (panel models, clustered by country)

\begin{tabular}{|c|c|c|c|c|c|}
\hline & (1) & (2) & (3) & (4) & (5) \\
\hline Main expl. var. & cattle & meat & milk & cattle only & mortality only \\
\hline \multirow[t]{2}{*}{ Cattle (ln, p.c.) } & $0.47 *$ & & & $0.82 * * *$ & \\
\hline & $(0.079)$ & & & $(0.001)$ & \\
\hline \multirow[t]{2}{*}{ Infant mortality (ln) } & $-1.65 * * *$ & $-1.46 * * *$ & $-1.36 * * *$ & & $-1.99 * * *$ \\
\hline & $(0.000)$ & $(0.001)$ & $(0.002)$ & & $(0.000)$ \\
\hline \multirow[t]{2}{*}{ Mountains } & $-0.03 * *$ & $-0.06^{* *}$ & $-0.07 * * *$ & & \\
\hline & $(0.019)$ & $(0.028)$ & $(0.005)$ & & \\
\hline \multirow[t]{2}{*}{ Civil war } & 0.25 & & & & \\
\hline & $(0.448)$ & & & & \\
\hline \multirow[t]{2}{*}{ Meat (ln, p.c.) } & & $0.51 * *$ & & & \\
\hline & & $(0.032)$ & & & \\
\hline \multirow[t]{2}{*}{ Milk (ln, p.c.) } & & & $0.37 * *$ & & \\
\hline & & & $(0.045)$ & & \\
\hline \multirow[t]{2}{*}{ Democracy } & & $0.40 * * *$ & & & \\
\hline & & $(0.007)$ & & & \\
\hline Time Fixed Effects & YES & YES & YES & YES & YES \\
\hline World region-fixed effects & YES & NO & NO & NO & NO \\
\hline Constant & 171.95 & 179.81 & 178.90 & 161.81 & 174.61 \\
\hline Observations & 417 & 219 & 200 & 604 & 551 \\
\hline Number of countries & 77 & 58 & 53 & 103 & 106 \\
\hline R-squared (within) & 0.92 & 0.88 & 0.9 & 0.82 & 0.91 \\
\hline $\mathrm{R}$-squared (overall) & 0.73 & 0.6 & 0.62 & 0.29 & 0.45 \\
\hline
\end{tabular}

Note: robust p-values in brackets based standard errors are clustered by country to avoid potential consequences of serial correlation, and to provide heteroskedasticity-robust and cluster-robust estimates, see Cameron/Trivedi (2009), p. 85. *, **, *** refer to significance levels of 1, 5, and 10 percent. Estimates are random effects panel estimates. Fixed effects estimates are not plausible for such a long time frame, as it seems unlikely that country effects remain unchanged for two centuries, which is an assumption required for fixed effects estimation. For data characteristics see Table 5. Dummies for all potential biases such as data set based on prison registers, volunteer army etc. included (see Baten and Blum 2012a). The relatively high R-square values are partly caused by the time and region fixed effects dummies, and hence should not be interpreted as explanatory power. Constants are all significant at 1 percent level. 
Table 6. Determinants of height (BETA coefficients)

\begin{tabular}{lccccc}
\hline \hline & $(1)$ & $(2)$ & $(3)$ & $(4)$ & $(5)$ \\
\hline & cattle & cattle only & mortality only cattle \& GDP mort. \& GDP \\
Cattle (ln, p.c.) & $1.10^{* * * *}$ & $1.21^{* * *}$ & & $0.89^{* * *}$ & \\
& $(0.000)$ & $(0.000)$ & & $(0.000)$ & \\
Infant mortality (ln) & $-1.79 * * *$ & & $-2.92^{* * *}$ & & $-2.06^{* * *}$ \\
& $(0.000)$ & & $(0.000)$ & & $(0.000)$ \\
GDP/c (ln) & & & & $1.79 * * *$ & $1.26 * * *$ \\
& & & & $(0.000)$ & $(0.000)$ \\
Mountains & $-0.03 * * *$ & & & & \\
& $(0.000)$ & & & & \\
Civil war & -0.97 & & & & \\
& $(0.114)$ & & & & \\
Time Fixed Effects & YES & YES & YES & YES & YES \\
World region-fixed effects & YES & NO & NO & NO & NO \\
Constant & 183.55 & 165.05 & 180.72 & 151.91 & 167.15 \\
& & & & & \\
Observations & 417 & 604 & 551 & 455 & 466 \\
Adj. R-squared & 0.74 & 0.45 & 0.56 & 0.53 & 0.56 \\
\hline \hline
\end{tabular}

Note: see notes to Table 5. The relatively high R-square values are partly caused by the time and region fixed effects dummies, and hence should not be interpreted as explanatory power. Constants are all significant at 1 percent level. 
Table 7. Determinants of height - Cattle instrumented with lactose intolerance

\begin{tabular}{lccc}
\hline \hline Estimation technique & 2SLS & LIML & LIML \\
\hline First Stage & & & \\
Lactose tolerance & 0.93 & & \\
& $(0.058)$ & & \\
Robust F & 3.548 & & \\
& $(0.066)$ & & \\
Second Stage & & & \\
Cattle (ln) & $3.91 * *$ & $3.91 * *$ & $5.40 *$ \\
& $(0.041)$ & $(0.041)$ & $(0.061)$ \\
Infant mortality (ln) & 0.37 & 0.37 & -0.18 \\
& $(0.677)$ & $(0.677)$ & $(0.867)$ \\
GDP/c (ln) & \multicolumn{3}{c}{-2.68} \\
& & & $(0.239)$ \\
Mountain share & $-0.04 * *$ & $-0.04 * *$ & -0.03 \\
& $(0.041)$ & $(0.041)$ & $(0.146)$ \\
Time-fixed effects & YES & YES & YES \\
Region-fixed effects & YES & YES & YES \\
Constant & 169.03 & 169.03 & 193.78 \\
Observations & 296 & 296 & 268 \\
R-squared & 0.69 & 0.69 & 0.66 \\
\hline \hline
\end{tabular}

Note: robust p-values in brackets based standard errors are clustered by country. *, **, *** refer to significance levels of 1 , 5 , and $10 \%$. Dummies for all potential biases such as data set based on prison registers, volunteer army etc. included (see Baten and Blum 2012a). The relatively high R-square values are partly caused by the time and region fixed effects dummies, and hence should not be interpreted as explanatory power. As a caveat, we would like to note that lactose intolerance IV is cross-sectional in nature. Remember, however, that the cross-sectional component is much more important than the time series component (we have a typical large $\mathrm{N}$ - small $\mathrm{T}$ sample). In the very long run, lactose intolerance can be endogenous, but two centuries are not long-run for this type of effect. Constants are all significant at 1 percent level. 
Table 8. Determinants of height, early and late periods

\begin{tabular}{llllll}
\hline \hline & $(1)$ & $(2)$ & $(3)$ & $(4)$ & $(5)$ \\
\hline Period & overall & early & early & late & late \\
& & & & & \\
Cattle (ln) & $1.10^{* * *}$ & $1.37 * *$ & $0.92^{* *}$ & 0.61 & $0.75^{*}$ \\
& $(0.003)$ & $(0.033)$ & $(0.041)$ & $(0.156)$ & $(0.061)$ \\
Infant mortality (ln) & $-1.80^{* *}$ & $-3.37 * *$ & $-5.54 * * *$ & -1.19 & -1.73 \\
& $(0.021)$ & $(0.013)$ & $(0.000)$ & $(0.145)$ & $(0.122)$ \\
Mountain share & $-0.03^{* *}$ & -0.01 & -0.03 & $-0.05^{* * *}$ & $-0.06^{* * *}$ \\
& $(0.030)$ & $(0.651)$ & $(0.307)$ & $(0.002)$ & $(0.008)$ \\
Time fixed effects & Yes & Yes & Yes & Yes & Yes \\
Region fixed effects & Yes & Yes & No & Yes & No \\
& & & & & \\
Constant & 183.53 & 187.38 & 196.53 & 182.24 & 179.94 \\
& & & & & \\
Observations & 417 & 175 & 175 & 190 & 190 \\
Adj. R-sq. & 0.74 & 0.68 & 0.53 & 0.78 & 0.58 \\
\hline \hline
\end{tabular}

Note: robust p-values in brackets based standard errors are clustered by country. $*, * *, * * *$ refer to significance levels of 1,5 , and $10 \%$. Dummies for all potential biases such as data set based on prison registers, volunteer army etc. included (see Baten and Blum 2012a). Constants are all significant at 1 percent level. 
Table 9. World region dummies - Lower-bound estimates of the effects of food behaviour, intergenerational effects, culture, and other unobservable factors

\begin{tabular}{lll}
\hline \hline & $\begin{array}{l}\text { Effects of genetics etc. } \\
\text { (regr. with explan. var.) }\end{array}$ & $\begin{array}{l}\text { Overall region effect } \\
\text { (without expl. var.) }\end{array}$ \\
\hline East Asia & $-3.97 * * *$ & $-8.22 * * *$ \\
& $(0.001)$ & $(0.000)$ \\
East. Eur./Cntr. Asia & 0.15 & $-0.98^{*}$ \\
& $(0.778)$ & $(0.051)$ \\
Latin America/Car. & $-4.44 * * *$ & $-8.33^{* * *}$ \\
& $(0.000)$ & $(0.000)$ \\
Mid. East/N. Afr. & -0.98 & $-5.98^{* * *}$ \\
& $(0.227)$ & $(0.000)$ \\
North America/Au/Nz & $1.84 * * *$ & $2.71 * * *$ \\
& $(0.000)$ & $(0.000)$ \\
South Asia & $-3.83 * * *$ & $-7.16 * * *$ \\
Southeast Asia & $(0.000)$ & $(0.000)$ \\
& $-7.54 * * *$ & $-13.11^{* * *}$ \\
Subsaharan Africa & $(0.000)$ & $(0.000)$ \\
Western Eur. & $-2.20 * *$ & $-5.60 * * *$ \\
\hline \hline
\end{tabular}

Note: robust p-values in brackets. *,**,*** refer to significance levels of 1,5 , and $10 \%$. Included explanatory variables are cattle, infant mortality, mountain, civil war, lactose, birth decade. OLS estimation. "East. Eur./Cntr. Asia"= Eastern Europe and formerly members of the Soviet Union. 